\title{
Er en belastet barndom knyttet til kortere telomerer?
}

\begin{abstract}
BAKGRUNN Det er vist at alvorlig belastning i barndommen er skadelig for senere helse. Ny forskning er rettet mot om - og eventuelt hvordan - telomerene, de beskyttende endestykkene på kromosomene, kan være et av bindeleddene mellom slik erfaring og senere sykelighet. Vi presenterer her en oversikt over studier der man har sett på sammenhengen mellom belastning i barndommen og telomerlengde.
\end{abstract}

KUNNSKAPSGRUNNLAG Oversikten favner 26 originalstudier funnet ved litteraturs $ø$ k i PubMed. Vi inkluderte studier over forholdet mellom telomerlengde og ulike belastende forhold fra unnfangelsen og gjennom hele oppveksten.

RESULTATER Studiene ble gruppert etter fire temaer. Forskningsgrunnlaget på morens stress i svangerskapet og foreldrenes omsorgsevne er for lite til å si noe konklusivt. Psykososial belastning i barndommen var knyttet til kortere telomerlengde i 12 av 14 studier. Sosioøkonomisk status i barndommen var ikke entydig knyttet til telomerlengde.

FORTOLKNING Kortere telomerer er muligens knyttet til psykososial belastning i barndommen. Forskningsfeltet er ennå ungt, og det er behov for flere longitudinelle studier med vekt på barndomserfaring samt en samordning av målevariabler og resultatmål for å kunne bekrefte en slik sammenheng.

Belastning i barndommen, slik som mishandling, omsorgssvikt eller fattigdom, er forbundet med økt sykelighet og dødelighet som voksen (1-3). Blant annet har lav sosioøkonomisk status, både som barn og voksen, lenge vært kjent som en slik risikofaktor $(4,5)$. Hos barn er det vist at alvorlig belastning henger sammen med endret hjernestruktur, stressrespons og immunitet (5), i tillegg til økt risikoatferd slik som røyking og rusmisbruk som voksen (6).

De siste årene har forskning vært rettet mot om - og eventuelt hvordan - telomerer kan være et av bindeleddene mellom destruktiv barndomserfaring og senere helse. Telomerer er bygd opp av repetitive DNA-sekvenser (7, 8). De danner beskyttende endestykker på kromosomene og forkortes ved hver celledeling (8). Når telomerene når en kritisk lengde, går cellen inn $\mathrm{i}$ apoptose eller senescence, en tilstand der de ikke kan dele seg lenger (8). Enzymet telomerase opprettholder lengden på telomerene i stamceller, men klarer ikke å motvirke telomerforkorting over tid i somatiske celler (8). Basert på gjennomsnittlig telomertap ved aldring kan man anslå hvor mange år «eldre» cellene til en gruppe er sammenliknet med en annen.

Kortere telomerer er blitt knyttet til økt sykelighet og dødelighet (8), selv om sammenhengen ikke er entydig (9). I tillegg til genetisk variasjon er telomerlengde også sterkt knyttet til alder, rase og kjønn samt $i$ mindre grad til kroppsmasseindeks, livsstil og sosioøkonomisk status (10). I en rekke studier har man knyttet kortere telomerer til belastende psykososiale forhold hos voksne
(11). I denne oversiktsartikkelen vil vi oppsummere forskningen på sammenhengen mellom belastende barndomsforhold og telomerlengde.

\section{Kunnskapsgrunnlag}

Vi søkte etter studier i databasen PubMed med søkekombinasjonen «telomere AND ('psychological stress' OR 'social environment' OR socioeconomic OR abuse OR neglect OR 'early life stress').» Søket resulterte i 221 artikler. Originalstudier publisert før 14.3. 2015 på engelsk eller skandinaviske språk som omhandlet både belastende barndomsforhold og måling av telomerlengde, ble inkludert. Studier ble inkludert på grunnlag av tittel, men der tittelen ikke klart viste om studien fylte kriteriene, ble også sammendraget lest. 26 studier fylte inklusjonskriteriene og ble dermed tatt med i oversikten.

\section{Resultater}

Resultatene er presentert kortfattet i tabell 1 $(12-37)$. Vi delte de inkluderte studiene inn etter fire temaer:

- Studier der man målte stress hos mor $i$ svangerskapet

- Studier der foreldrenes omsorgsevne ble målt

- Under temaet psykososial belastning i barndommen inkluderte vi alle studiene som omhandlet ulike typer belastninger, slik som fysisk og psykisk vold og omsorgssvikt, eller ulike hendelser, slik som skilsmisse og tap av foreldre gjennom barndommen

- Studier der man hovedsaklig målte sosioøkonomisk status i barndommen

\section{Ane Brandtzæg Næss \\ ane.b.naess@hotmail.com \\ Universitetet i Oslo}

\section{Anna Luise Kirkengen}

Allmennmedisinsk forskningsenhet Institutt for samfunnsmedisin

Norges teknisk-naturvitenskapelige universitet og

Institutt for samfunnsmedisin

Universitetet i Troms $\emptyset$ - Norges arktiske universitet

\section{HOVEDBUDSKAP}

I mange studier ser man en sammenheng mellom belastende barndomsforhold og kortere telomerer, selv om forskningsgrunnlaget ikke er entydig

Den robuste sammenhengen mellom belastning i barndommen og redusert voksenhelse kan være mediert av blant annet redusert telomerlengde 
Det var en viss grad av overlapp mellom gruppene, hvilket vi har gjort rede for i teksten og tabell 1.

\section{Morens stress i svangerskapet}

I de to studiene vi fant $(12,13)$ var stress, målt som enten belastende hendelser (12) eller stor bekymring rundt svangerskap og fødsel (13), knyttet til rundt 3,5 år «eldre» celler hos barna som voksne i den ene studien (12) og ansvarlig for $25 \%$ av variansen i telomerlengde hos nyfødte i den andre (13).

\section{Foreldrenes omsorgsevne}

Lav omsorgsevne var knyttet til kortere telomerlengde hos barn (14) og afroamerikanske ungdommer (15), men kun når forholdene rundt barna ellers var dårligere enn for kontrollgruppen. Barn med høy risiko for mishandling, målt ved om foreldrene var i kontakt med barnevernet, hadde kortere telomerlengde enn barn uten slik risiko (14). Bare i høyrisikogruppen var god omsorgsevne hos foreldrene knyttet til lengre telomerer hos barna. Brody og medarbeidere fant at ungdom med ikke-støttende foreldre hadde kortere telomerlengde enn ungdom med støttende foreldre, men denne sammenhengen gjaldt bare for gruppen som ikke hadde deltatt i et atferdsendringsprogram for foreldre og ungdom (15).

Psykososial belastning i barndommen

I 14 studier undersøkte man sammenhengen mellom ulike typer belastning i barndommen og telomerlengde enten hos barn (16-19) eller voksne (20-29). Studiene var hovedsakelig tverrsnittstudier med retrospektiv angivelse av hendelser i barndommen. Belastning i barndommen ble registrert longitudinelt i fire studier $(16,17,19,26)$, og $i$ en av disse målte man også telomerlengde over tid (17). I to studier ble det ikke funnet noen sammenheng mellom barndomserfaringer og telomerlengde $(20,26)$, hvorav den ene målte belastninger longitudinelt $i$ en fødselskohort (26). I de resterende 12 studiene fant man at kortere telomerlengde hang sammen med noen eller alle av studienes mål på psykososial belastning i barndommen.

I tre studier ble det angitt hvor stor andel av variansen i telomerlengde som kunne forklares av psykososial belastning (16, 19, 27). Denne ble målt til $0,4-1,2 \%$ (27) $12,2 \%$ (16) og $40 \%$ (19). Et dose-responsforhold mellom antall typer belastninger og telomerlengde som voksen ble rapportert $\mathrm{i}$ tre studier $(21,24,25)$. I en av disse fant man at hver «ekstra» type belastning var assosiert med tre år «ekstra» aldring (25), de andre oppga ikke resultatmålet $\mathrm{i}$ denne formen.

Alle de fire studiene der man målte telomerlengde hos barn (16-19) fant man at psykososial belastning var assosiert med kortere telomerlengde. En større andel av livet tilbrakt på barnehjem var knyttet til kortere telomerlengde hos rumenske barn som ble fulgt over tid (16). Barn som ble utsatt for to eller flere typer vold i 5-10 års alder hadde signifikant raskere forkortning av telomerene over denne perioden sammenliknet med andre barn (17). Det å vokse opp i familier med ulike problemer, slik som foreldre i ustabile forhold, i fengsel eller med familievold, var også knyttet til kortere telomerlengde hos barn $(18,19)$.

\section{Sosioøkonomisk status i barndommen}

Hvordan sosioøkonomisk status i barndommen hang sammen med telomerlengde ble undersøkt i 12 studier $(19,21,25,29-37)$, hvorav fire også er nevnt $i$ avsnittet over (19, $21,25,29$ ). I flere av disse studiene ble store kohorter fulgt med tanke på sosioøkonomisk status i barndom og voksenliv (tab 1). I en multietnisk amerikansk studie fant man at det å ha en lavt utdannet far var knyttet til lengre telomerlengde $(0,7 \%$ av variansen $)$, men kun hos latinamerikanere (35). Det var ingen sammenheng mellom valgte mål på sosioøkonomisk status i barndommen og telomerlengde som voksen i fire av studiene $(25,29-31)$. I tre studier fant man at bare noen av de valgte målene på sosioøkonomisk status hang sammen med kortere telomerlengde som voksen $(21,32,34)$. I en skotsk fødselskohort fra 1970-årene var for eksempel det å vokse opp i en familie i en lav sosial klasse eller uten egen bil, knyttet til henholdsvis nesten 20 og 8,5 år «eldre» celler (34). Sammenhengen gjaldt derimot ikke for andre mål på sosioøkonomisk status i barndommen og heller ikke for kohortene født i 1930- og 50-årene i samme studie (34).

I tre studier målte man sosioøkonomisk status og telomerlengde hos barn $(19,33,37)$. Barn med lavt utdannede foreldre hadde kortere telomerlengde, tilsvarende seks års «ekstra» aldring, sammenliknet med barn der minst én av foreldrene hadde høyere utdanning (33). Familieøkonomien påvirket ikke telomerlengde $\mathrm{i}$ denne studien. Derimot fant man $i$ en annen studie at en dobling av familiens inntekt hang sammen med 5\% lengre telomerer, og at barn av mødre med lav utdanning hadde rundt $30 \%$ kortere telomerer enn andre barn (19). I den tredje studien hadde barn fra veldig urolige og fattige nabolag lavere telomerlengde enn gjennomsnittet (37).

\section{Diskusjon}

\section{Barndomsforhold og telomerlengde}

Studiene på sammenhengen mellom henholdsvis morens stress i svangerskapet og foreldrenes omsorgsevne og telomerlengde hos barna er for små og begrensede til at det kan trekkes en sikker slutning. Resultatene er mest konsistente når det gjelder psykososial belastning og telomerlengde. 12 av 14 studier viser at ulike mål for slik belastning henger sammen med kortere telomerlengde både hos voksne og barn. Dette passer med konklusjonen i en oversiktsstudie over temaet fra 2013 (38). Om sosioøkonomisk status i barndommen er knyttet til kortere telomerlengde, er mer usikkert. I studiene har man utforsket ulike mål på sosioøkonomisk status og har kommet frem til motsetningsfylte resultater.

\section{Metodologiske problemer}

Studiene i oversikten viser en heterogenitet av målevariabler som går utover det vår tabell fremstiller. Dermed blir det vanskelig å trekke konklusjoner basert på studiene sett under ett. Heterogeniteten kan skyldes at man fortsatt ikke har et begrepsapparat for hvilke typer erfaring som er entydig belastende. Noe slikt ville i seg selv være problematisk, da erfaring er subjektiv og kontekstavhengig. Videre oppgir studieforfatterne vidt forskjellige resultatmål for telomerlengde. Dette gjør det vanskelig å sammenlikne resultatene av studiene og umulig å utføre en metaanalyse.

Studiene i oversikten er kontrollert for en rekke faktorer som er vist å henge sammen med telomerlengde, slik som kjønn og alder. Det er imidlertid en svakhet at studiene ikke alltid er kontrollert for de samme faktorene.

For å avgjøre om belastende barndomserfaringer fører til forkortning av telomerer, trengs det flere longitudinelle studier der man måler telomerlengde over tid. Hittil finnes det kun én slik (17). Siden telomerforkortning foregår sakte, er det anbefalt at man i longitudinelle studier bør måle forandring over flere tiår for å oppnå mer pålitelige resultater (10). Dessuten er erfaringer i sin natur subjektive fenomener. Dermed er de ikke målbare slik som en objektivt definert hendelse er. Samtidig er det subjektets tolkning av egne erfaringer som trolig avgjør hvordan disse påvirker senere helse. Det er en utfordring å inkludere disse aspektene i videre forskning.

Telomerlengde måles på ulike måter i flere av studiene. De fleste har brukt celler fra perifert blod (leukocytter) og polymerasekjedereaksjonstest (PCR), mens noen få har brukt Southern blotting (tab 1). Det er vist akseptabelt samsvar mellom metodene, men PCR er beheftet med større målefeil (39). I noen få studier har man brukt celler fra munnens slimhinne (16), men det hersker fortsatt uenighet om telomerlengde i ulike vev kan sammenliknes $(9,40)$.

\section{Mulige mekanismer}

Det finnes flere hypoteser om virkningen av belastning $\mathrm{i}$ barndommen på både telomerer og senere sykdomsutvikling. Antakelig er mange mekanismer involvert. Atferdsendringer som følge av en oppvekst $i$ et truende 
Tabell 1 Oversikt over 26 originalstudier der man har sett på forholdet mellom telomerlengde og ulike belastende forhold fra unnfangelsen og gjennom hele oppveksten. I alle studiene er telomerlengde målt ved ett tidspunkt hos voksne kvinner og menn dersom ikke annet er spesifisert. $\mathrm{PB}=$ perifert blod, $\mathrm{PCR}=$ polymerasekjedereaksjonstest, NSB = navlestrengsblod, $\mathrm{MS}=$ munnslimhinne, SB = Southern blotting

\begin{tabular}{|c|c|c|c|c|c|c|}
\hline $\begin{array}{l}\text { Første- } \\
\text { forfatter }\end{array}$ & År og land & Mål på belastning & Design/deltakere & $\begin{array}{l}\text { Vevstype/ } \\
\text { telomer- } \\
\text { mål }\end{array}$ & Kontrollert for & Hovedfunn \\
\hline $\begin{array}{l}\text { Entringer } \\
\text { (12) }\end{array}$ & 2011 Tyskland & $\begin{array}{l}\text { Alvorlig belastning } \\
\text { i svangerskapet }\end{array}$ & $\begin{array}{l}\text { Pasientkontroll, } \\
\mathrm{N}=94 ; \text { mor med } \\
\text { belastning ( } \mathrm{n}=45) \\
\text { og uten belastning } \\
\text { ( } \mathrm{n}=49 \text { ) }\end{array}$ & $\begin{array}{l}\mathrm{PB} \\
\mathrm{PCR}\end{array}$ & $\begin{array}{l}\text { Alder, kjønn, BMI, } \\
\text { sosioøkonomisk } \\
\text { status, fødselsvekt, } \\
\text { belastning i barn- } \\
\text { dommen, sykdom, } \\
\text { røyking, risiko i svan- } \\
\text { gerskapet }\end{array}$ & $\begin{array}{l}\text { Alvorlig belastning var signifi- } \\
\text { kant assosiert med kortere } \\
\text { telomerlengde hos barna som } \\
\text { unge voksne }\end{array}$ \\
\hline $\begin{array}{l}\text { Entringer } \\
\text { (13) }\end{array}$ & 2013 USA & $\begin{array}{l}\text { Graviditetsspesifikt } \\
\text { stress i svanger- } \\
\text { skapet }\end{array}$ & $\begin{array}{l}\text { Tverrsnitt, } N=27 \text {, } \\
\text { mor-nyfødt-dyader }\end{array}$ & $\begin{array}{l}\text { NSB } \\
\text { PCR }\end{array}$ & $\begin{array}{l}\text { Svangerskaps- } \\
\text { lengde- og komplika- } \\
\text { sjoner, fødselsvekt, } \\
\text { kjønn }\end{array}$ & $\begin{array}{l}\text { Kortere telomerlengde hos } \\
\text { nyfødte var signifikant assosiert } \\
\text { med graviditetsspesifikt stress }\end{array}$ \\
\hline Asok (14) & 2013 USA & $\begin{array}{l}\text { Foreldres omsorgs- } \\
\text { evne og responsivitet }\end{array}$ & $\begin{array}{l}\text { Pasientkontroll, } \\
\mathrm{N}=89 \text { barn med } \\
\text { risiko for mishand- } \\
\text { ling ( } \mathrm{n}=51 \text { ) og uten } \\
\text { risiko }(\mathrm{n}=38)\end{array}$ & $\begin{array}{l}\text { MS } \\
\text { PCR }\end{array}$ & $\begin{array}{l}\text { Sosioøkonomisk } \\
\text { status, fødselsvekt, } \\
\text { kjønn, minoritets- } \\
\text { bakgrunn }\end{array}$ & $\begin{array}{l}\text { Høyrisikobarn hadde signifi- } \\
\text { kant kortere telomerlengde. } \\
\text { Responsive foreldre modererte } \\
\text { assosiasjonen mellom risiko } \\
\text { og telomerlengde }\end{array}$ \\
\hline Brody (15) & 2015 USA & $\begin{array}{l}\text { Foreldres omsorgs- } \\
\text { evne (støtte/ikke- } \\
\text { støtte) }\end{array}$ & $\begin{array}{l}\text { Pasientkontroll, } \\
\mathrm{N}=216 \text { ungdommer; } \\
\text { Intervensjon ( } \mathrm{n}=114 \text { )/ } \\
\text { ikke intervensjon } \\
\text { ( } \mathrm{n}=102)\end{array}$ & $\begin{array}{l}\mathrm{PB} \\
\mathrm{PCR}\end{array}$ & $\begin{array}{l}\text { Kjønn, sosioøkono- } \\
\text { misk status, aktuelt } \\
\text { stress, røyking, alko- } \\
\text { holbruk, BMI, blod- } \\
\text { trykk }\end{array}$ & $\begin{array}{l}\text { Kortere telomerlengde ved } \\
22 \text { års alder var signifikant } \\
\text { assosiert med ikke-støttende } \\
\text { foreldrestil ved } 17 \text { års alder, } \\
\text { men bare i kontrollgruppen }\end{array}$ \\
\hline Tyrka (22) & 2010 USA & $\begin{array}{l}5 \text { typer belastende } \\
\text { barndomserfaringer }\end{array}$ & $\begin{array}{l}\text { Tverrsnitt, } \\
\mathrm{N}=31\end{array}$ & $\begin{array}{l}\mathrm{PB} \\
\mathrm{PCR}\end{array}$ & $\begin{array}{l}\text { Alder, røyking, BMI, } \\
\text { hormonell preven- } \\
\text { sjon, minoritet, } \\
\text { sosioøkonomisk } \\
\text { status, aktuelt stress }\end{array}$ & $\begin{array}{l}\text { Belastende barndomserfaring } \\
\text { var signifikant assosiert med } \\
\text { kortere telomerlengde }\end{array}$ \\
\hline Glass (20) & 2010 England & $\begin{array}{l}3 \text { typer belastende } \\
\text { barndomserfaringer }\end{array}$ & Kohort, N = 1871 & $\begin{array}{l}\text { PB } \\
\text { SB }\end{array}$ & $\begin{array}{l}\text { Alder, kjønn, røyking, } \\
\text { BMI }\end{array}$ & $\begin{array}{l}\text { Ingen sammenheng mellom } \\
\text { belastende barndomserfaring } \\
\text { og telomerlengde ble påvist. }\end{array}$ \\
\hline $\begin{array}{l}\text { Kananen'1 } \\
\text { (21) }\end{array}$ & 2010 Finland & $\begin{array}{l}11 \text { typer belastende } \\
\text { barndomserfaringer }\end{array}$ & $\begin{array}{l}\text { Pasientkontroll, } \\
N=974 ; \text { med angst } \\
(n=321) / \text { kontroll } \\
(n=653)\end{array}$ & $\begin{array}{l}\mathrm{PB} \\
\mathrm{PCR}\end{array}$ & Alder, kjønn. & $\begin{array}{l}\text { Belastende barndomserfaring } \\
\text { var signifkant assosiert i et } \\
\text { dose-respons-forhold med } \\
\text { kortere telomerlengde i begge } \\
\text { grupper }\end{array}$ \\
\hline $\begin{array}{l}\text { Surtees }{ }^{1} \\
\text { (25) }\end{array}$ & 2011 England & $\begin{array}{l}8 \text { typer belastende } \\
\text { barndomserfaringer }\end{array}$ & $\begin{array}{l}\text { Tverrsnitt, } N=4441 \\
\text { kvinner }\end{array}$ & $\begin{array}{l}\text { PB } \\
\text { PCR }\end{array}$ & $\begin{array}{l}\text { Helse, sosioøkono- } \\
\text { misk status, over- } \\
\text { vekt, røyking }\end{array}$ & $\begin{array}{l}\text { Kortere telomerlengde var sig- } \\
\text { nifikant assosiert med økende } \\
\text { antall belastende barndoms- } \\
\text { erfaring }\end{array}$ \\
\hline $\begin{array}{l}\text { O'Donovan } \\
\text { (24) }\end{array}$ & 2011 USA & $\begin{array}{l}5 \text { typer belastende } \\
\text { barndomserfaringer }\end{array}$ & $\begin{array}{l}\text { Pasientkontroll, } \\
N=90 ; \text { PTSD } \\
\text { (n=43)/kontroll } \\
(n=47)\end{array}$ & $\begin{array}{l}\text { PB } \\
\text { PCR }\end{array}$ & Alder & $\begin{array}{l}\text { Kortere telomerlengde var } \\
\text { signifikant assosiert med } \\
\text { belastende barndomserfaring } \\
\text { hos personer med posttrauma- } \\
\text { tisk stressforstyrrelse }\end{array}$ \\
\hline $\begin{array}{l}\text { Kiecolt- } \\
\text { Glaser (23) }\end{array}$ & 2011 USA & $\begin{array}{l}11 \text { typer belastende } \\
\text { barndomserfaringer }\end{array}$ & $\begin{array}{l}\text { Pasientkontroll } \\
\text { (undergruppe), } \\
\mathrm{N}=86 \text {; omsorg for } \\
\text { demente/kontroll }\end{array}$ & $\begin{array}{l}\text { PB } \\
\text { SB }\end{array}$ & $\begin{array}{l}\text { Alder, kjønn, BMI, } \\
\text { omsorgsansvar }\end{array}$ & $\begin{array}{l}\text { Kortere telomerlengde var } \\
\text { signifikant assosiert med nega- } \\
\text { tive hendelser i barndommen, } \\
\text { men ikke med mishandling } \\
\text { i begge grupper }\end{array}$ \\
\hline $\begin{array}{l}\text { Savolainen } \\
\text { (27) }\end{array}$ & 2014 Finland & $\begin{array}{l}1 \text { type belastende } \\
\text { barndomserfaring }\end{array}$ & Tverrsnitt, $N=1486$ & $\begin{array}{l}\mathrm{PB} \\
\mathrm{PCR}\end{array}$ & $\begin{array}{l}\text { Alder, kjønn, prøve- } \\
\text { kvalitet (DNA), helse, } \\
\text { BMI, sosioøkonomisk } \\
\text { status (voksen og } \\
\text { barndom), røyking, } \\
\text { fysisk aktivitet, alko- } \\
\text { holbruk, morens alder }\end{array}$ & $\begin{array}{l}\text { Kortere telomerlengde var } \\
\text { signifikant assosiert med } \\
\text { belastende barndomserfaring } \\
\text { (evakuering som barn) hos per- } \\
\text { soner med senere traumatisk } \\
\text { erfaring i tillegg }\end{array}$ \\
\hline Zalli (28) & 2014 England & $\begin{array}{l}5 \text { typer belastende } \\
\text { barndomserfaringer }\end{array}$ & Tverrsnitt, N = 333 & $\begin{array}{l}\text { PB } \\
\text { PCR }\end{array}$ & $\begin{array}{l}\text { Alder, kjønn, sosio- } \\
\varnothing k o n o m i s k \text { status, } \\
\text { BMI }\end{array}$ & $\begin{array}{l}\text { Kortere telomerlengde var } \\
\text { signifikant assosiert med tap } \\
\text { av mor som barn, men ikke } \\
\text { med andre typer belastende } \\
\text { barndomserfaring }\end{array}$ \\
\hline
\end{tabular}




\begin{tabular}{|c|c|c|c|c|c|c|}
\hline Jodczyk (26) & $\begin{array}{l}2014 \text { New } \\
\text { Zealand }\end{array}$ & $\begin{array}{l}4 \text { typer belastende } \\
\text { barndomserfaringer }\end{array}$ & $\begin{array}{l}\text { Fødselskohort, } \\
N=677\end{array}$ & $\begin{array}{l}\text { PB } \\
\text { PCR }\end{array}$ & $\begin{array}{l}\text { Kjønn, minoritet, } \\
\text { sosioøkonomisk } \\
\text { status ved fødsel }\end{array}$ & $\begin{array}{l}\text { Det var ikke assosiasjon mel- } \\
\text { lom telomerlengde og belas- } \\
\text { tende barndomserfaring }\end{array}$ \\
\hline Tyrka' (29) & 2015 USA & $\begin{array}{l}6 \text { typer belastende } \\
\text { barndomserfaringer }\end{array}$ & Tverrsnitt, $N=290$ & $\begin{array}{l}\text { PB } \\
\text { PCR }\end{array}$ & $\begin{array}{l}\text { Alder, kjønn, sosio- } \\
\text { økonomisk status } \\
\text { (voksen og barn- } \\
\text { dom), BMl }\end{array}$ & $\begin{array}{l}\text { Belastende barndomserfaring } \\
\text { var signifikant knyttet til kor- } \\
\text { tere telomerlengde }\end{array}$ \\
\hline Drury (16) & 2012 Romania & $\begin{array}{l}1 \text { type belastende } \\
\text { barndomserfaring }\end{array}$ & $\begin{array}{l}\text { Randomisert, kontrol- } \\
\text { lert, } N=136 \text { barn; } \\
\text { barnehjem }(n=68) / \\
\text { fosterhjem }(n=68)\end{array}$ & $\begin{array}{l}\text { MS } \\
\text { PCR }\end{array}$ & $\begin{array}{l}\text { Intervensjon, kjønn, } \\
\text { fødselsvekt, alder }\end{array}$ & $\begin{array}{l}\text { Kortere telomerlengde ved } \\
6-10 \text { års alder var signifikant } \\
\text { korellert med belastende } \\
\text { barndomserfaring (tid på } \\
\text { barnehjem før fire års alder) }\end{array}$ \\
\hline Shalev (17) & 2013 England & $\begin{array}{l}3 \text { typer belastende } \\
\text { barndomserfaringer }\end{array}$ & Kohort, $N=236$ barn & $\begin{array}{l}\text { MS } \\
\text { PCR }\end{array}$ & $\begin{array}{l}\text { Telomerlengde ved } \\
5 \text { års alder, kjønn, } \\
\text { sosioøkonomisk sta- } \\
\text { tus som barn, BMl }\end{array}$ & $\begin{array}{l}\text { Signifikant } \varnothing \text { kt tap av telomer- } \\
\text { lengde i } 5-10 \text { års alder ble vist } \\
\text { ved erfaring av to eller flere } \\
\text { belastende barndomserfarin- } \\
\text { ger (ulike typer vold) }\end{array}$ \\
\hline $\begin{array}{l}\text { Mitchell11 } \\
\text { (19) }\end{array}$ & 2014 USA & $\begin{array}{l}5 \text { typer belastende } \\
\text { barndomserfaringer }\end{array}$ & $\begin{array}{l}\text { Kohort (undergruppe), } \\
N=40 \text { barn }\end{array}$ & $\begin{array}{l}\text { MS } \\
\text { PCR }\end{array}$ & $\begin{array}{l}\text { Alder, minoritet, } \\
\text { kjønn, BMl }\end{array}$ & $\begin{array}{l}\text { Kortere telomerlengde var } \\
\text { signifikant assosiert med } \\
\text { belastende barndomserfaring } \\
\text { og lav sosioøkonomisk status }\end{array}$ \\
\hline Drury (18) & 2014 USA & $\begin{array}{l}3 \text { typer belastende } \\
\text { barndomserfaringer }\end{array}$ & Tverrsnitt, $N=80$ barn & $\begin{array}{l}\text { MS } \\
\text { PCR }\end{array}$ & $\begin{array}{l}\text { Kjønn, alder, mors } \\
\text { og fars alder ved } \\
\text { unnfangelse, minori- } \\
\text { tet, sosioøkonomisk } \\
\text { status som barn }\end{array}$ & $\begin{array}{l}\text { Kortere telomerlengde var } \\
\text { signifikant assosiert med } \\
\text { belastende barndomserfaring, } \\
\text { men bare hos jentene i et } \\
\text { dose-respons-forhold. }\end{array}$ \\
\hline Adams (30) & 2006 England & $\begin{array}{l}\text { Sosioøkonomisk sta- } \\
\text { tus - yrkesklasse til } \\
\text { familiens overhode }\end{array}$ & $\begin{array}{l}\text { Fødselskohort, } \\
N=318\end{array}$ & $\begin{array}{l}\text { PB } \\
\text { PCR }\end{array}$ & $\begin{array}{l}\text { Røyking, alkohol- } \\
\text { bruk, BMI, diett, } \\
\text { kjønn, farens alder }\end{array}$ & $\begin{array}{l}\text { Det var ingen assosiasjon mel- } \\
\text { lom sosioøkonomisk status } \\
\text { ved fødsel leneste măling) } \\
\text { og telomerlengde som voksen }\end{array}$ \\
\hline Batty (31) & $\begin{array}{l}2009 \text { Skott- } \\
\text { land }\end{array}$ & $\begin{array}{l}\text { Sosioøkonomisk } \\
\text { status - høyde som } \\
\text { voksen }\end{array}$ & $\begin{array}{l}\text { Pasientkontroll, } \\
\mathrm{N}=1542 \text { menn } \\
\text { med koronarsykdom } \\
(\mathrm{n}=484) / \text { uten koro- } \\
\text { narsykdom ( } \mathrm{n}=1058 \text { ) }\end{array}$ & $\begin{array}{l}\text { PB } \\
\text { PCR }\end{array}$ & $\begin{array}{l}\text { Alder, røyking, BMI, } \\
\text { alkoholbruk, syk- } \\
\text { dom, statiner }\end{array}$ & $\begin{array}{l}\text { Ingen assosiasjon mellom } \\
\text { sosioøkonomisk status som } \\
\text { barn og telomerlengde }\end{array}$ \\
\hline Carroll (35) & 2013 USA & $\begin{array}{l}\text { Sosioøkonomisk } \\
\text { status - foreldrenes } \\
\text { utdanningsnivå }\end{array}$ & Tverrsnitt, $N=963$ & $\begin{array}{l}\text { PB } \\
\text { PCR }\end{array}$ & $\begin{array}{l}\text { Kjønn, alder, minori- } \\
\text { tet, BMI, helse, fysisk } \\
\text { aktivitet, røyking, } \\
\text { diett. }\end{array}$ & $\begin{array}{l}\text { Lengre telomerlengde var } \\
\text { signifikant assosiert med far } \\
\text { med lav utdanning hos latin- } \\
\text { amerikanere, ikke assosiert } \\
\text { med mors utdanning }\end{array}$ \\
\hline $\begin{array}{l}\text { Kajantie } \\
\text { (32) }\end{array}$ & 2012 Finland & $\begin{array}{l}\text { Sosioøkonomisk } \\
\text { status - fars yrke } \\
(A, B), \text { foreldres } \\
\text { utdanningsnivå (C) }\end{array}$ & $\begin{array}{l}\text { Kohort, } N=2376 ; 3 \\
\text { kohorter }(A, B \circ g)\end{array}$ & $\begin{array}{l}\text { PB } \\
\text { PCR }\end{array}$ & $\begin{array}{l}\text { Alder, kjønn, morens } \\
\text { alder, sosioøkono- } \\
\text { misk status, røyking }\end{array}$ & $\begin{array}{l}\text { Sosioøkonomisk status } \\
\text { som barn var assosiert med } \\
\text { kortere telomerlengde i A og B } \\
(n=2142) \text {, ikke i C }(n=334)\end{array}$ \\
\hline $\begin{array}{l}\text { Robertson } \\
\text { (34) }\end{array}$ & $\begin{array}{l}2012 \text { Skott- } \\
\text { land }\end{array}$ & $\begin{array}{l}\text { Sosioøkonomisk } \\
\text { status - foreldres } \\
\text { yrkesklasse, usikker } \\
\text { familieøkonomi, egen } \\
\text { bil, subjektiv sosio- } \\
\varnothing \text { konomisk status }\end{array}$ & $\begin{array}{l}\text { Kohort, } N=2185 ; \text { født } \\
\text { i tiårene } 1930 \text { (A), } 1950 \\
\text { (B) og } 1970 \text { (C) }\end{array}$ & $\begin{array}{l}\text { PB } \\
\text { PCR }\end{array}$ & Kjønn & $\begin{array}{l}\text { Kortere telomerlengde var } \\
\text { assosiert med lav sosioøkono- } \\
\text { misk status (foreldres yrkes- } \\
\text { klasse, egen bill i barndommen } \\
\text { hos C (n = 755), men ikke hos } \\
\text { A og B }\end{array}$ \\
\hline Cohen (36) & 2013 USA & $\begin{array}{l}\text { Sosioøkonomisk } \\
\text { status - foreldrene } \\
\text { eide bolig }\end{array}$ & Tverrsnitt, $N=135$ & $\begin{array}{l}\text { PB } \\
\text { PCR }\end{array}$ & $\begin{array}{l}\text { Alder, kjønn, mino- } \\
\text { ritet, BMI, nevro- } \\
\text { tisisme }\end{array}$ & $\begin{array}{l}\text { Kortere telomerlengde var } \\
\text { signifikant assosiert med } \\
\text { færre barndomsår ( } 5-18 \text { år) } \\
\text { der foreldrene ikke eide egen } \\
\text { bolig }\end{array}$ \\
\hline $\begin{array}{l}\text { Needham } \\
\text { (33) }\end{array}$ & 2012 USA & $\begin{array}{l}\text { Sosioøkonomisk } \\
\text { status - foreldres } \\
\text { utdanningsnivå } \\
\text { og inntekt }\end{array}$ & Tverrsnitt, $N=70$ barn & $\begin{array}{l}\text { PB } \\
\text { PCR }\end{array}$ & $\begin{array}{l}\text { Kjønn, alder, minori- } \\
\text { tet, diett, fysisk akti- } \\
\text { vitet, BMI }\end{array}$ & $\begin{array}{l}\text { Kortere telomerlengde signi- } \\
\text { fikant assosiert med lavt } \\
\text { utdannede foreldre, ikke } \\
\text { med inntekt }\end{array}$ \\
\hline Theall (37) & 2013 USA & $\begin{array}{l}\text { Sosioøkonomisk } \\
\text { status -fattigdom } \\
\text { og uro i nabolaget }\end{array}$ & Tverrsnitt, N = 99 barn & $\begin{array}{l}\text { MS } \\
\text { PCR }\end{array}$ & $\begin{array}{l}\text { Kjønn, alder, antall } \\
\text { barn i familien, Sosio- } \\
\varnothing \text { konomisk status, } \\
\text { antall år bodd i nabo- } \\
\text { laget }\end{array}$ & $\begin{array}{l}\text { Kortere telomerlengde var } \\
\text { signifikant assosiert med } \\
\text { å bo i nabolag med høy grad } \\
\text { av uro og fattigdom }\end{array}$ \\
\hline
\end{tabular}


og stressende miljø, slik som uforholdsmessig årvåkenhet overfor farer, mistillit, dårlige relasjoner og usunn livsstil ( 41) kan føre til økt risiko for sykdom. Røyking, overvekt og lite fysisk aktivitet er også assosiert med kortere telomerlengde (42), men ikke alltid entydig (9).

Alvorlig belastning i barndommen fører til endret stressresponsivitet, både fysiologisk og psykologisk (41). Psykologisk stress er vist å henge sammen med økte kortisolnivåer, økt inflammasjon og økt oksidativt stress (43). Alle disse faktorene er igjen knyttet til kortere telomerlengde (43). Psykologisk stress kan også fremskynde aldringen av immunsystemet via økt reaktivering av latente virus og dermed øke slitasjen på T-celler (7). Når T-cellenes telomerer når en kritisk lengde, slutter de å kunne dele seg, og slike celler er in vitro vist å skille ut betennelsesfremmende cytokiner (7). Det kan kanskje skape en ond sirkel der psykologisk stress fører til økt kortisolproduksjon og oksidativt stress, økt aldring av immunsystemet, kortere telomerer, økt inflammasjon og igjen kortere telomerer.

\section{Konklusjon}

Alvorlig belastning i barndommen kan muligens knyttes til kortere telomerer. Forskningsgrunnlaget er fortsatt for lite, ungt og metodisk heterogent til at det kan sies med sikkerhet. Det trengs flere longitudinelle studier der deltakerne følges nøye, samt enighet om hvilke typer belastninger som skal eller kan måles og hvordan forskjeller i telomerlengde best skal fremstilles statistisk. Når det er sagt, er det allerede påvist en robust sammenheng mellom en vond og vanskelig barndom, dårlig omsorgsevne hos foreldre og lav sosioøkonomisk status på den ene siden, og senere dårlig helse på den andre. De til nå foreliggende funnene, også de fra telomerforskningen, gir all mulig grunn til å øke innsatsen i alle helserelaterte profesjoner og samfunnet som helhet for å forebygge alvorlig belastning hos barn.

\section{Ane Brandtzæg Næss (f. 1989)}

er medisinstudent og tidligere redaksjonssjef for Æsculap.

Forfatter har fylt ut ICMJE-skjemaet og oppgir ingen interessekonflikter

\section{Anna Luise Kirkengen (f. 1946)}

er spesialist i allmennmedisin og professor II. Forfatter har fylt ut ICMJE-skjemaet og oppgir ingen interessekonflikter.

\section{Litteratur}

1. Brown DW, Anda RF, Tiemeier $\mathrm{H}$ et al. Adverse childhood experiences and the risk of premature mortality. Am J Prev Med 2009; 37: 389-96.

2. Wegman HL, Stetler C. A meta-analytic review of the effects of childhood abuse on medical out- comes in adulthood. Psychosom Med 2009; 71: $805-12$

3. Kelly-Irving M, Lepage B, Dedieu D et al. Adverse childhood experiences and premature all-cause mortality. Eur J Epidemiol 2013; 28: 721-34.

4. Marmot M, Brunner E. Cohort profile: the Whitehall II study. Int J Epidemiol 2005: 34: 251 -6.

5. Shonkoff JP, Garner AS. The lifelong effects of early childhood adversity and toxic stress. Pediatrics 2012; 129: e232-46.

6. Felitti V, Anda R. The lifelong effects of adverse childhood experiences. I. Chadwick D, Alexander R, Giardino A et al, red. Chadwick's child maltreatment. 4. utg. St. Louis, MO: STM Learning, 2014

7. Effros RB. Stress and immune system aging. I: Segerstrom SC, red. The Oxford handook of psychoneuroimmunology. Oxford: Oxford University Press, 2012

8. Bojesen SE. Telomeres and human health. J Intern Med 2013; 274: 399-413.

9. Weischer M, Bojesen SE, Nordestgaard BG. Telomere shortening unrelated to smoking, body weight, physical activity, and alcohol intake: 4,576 general population individuals with repeat measurements 10 years apart. PLoS Genet 2014; 10 e1004191.

10. Sanders JL, Newman AB. Telomere length in epidemiology: a biomarker of aging, age-related disease, both, or neither? Epidemiol Rev 2013; 35: 112-31.

11. Starkweather AR, Alhaeeri AA, Montpetit A et al. An integrative review of factors associated with telomere length and implications for biobehavioral research. Nurs Res 2014: 63: 36-50.

12. Entringer S, Epel ES, Kumsta R et al. Stress exposure in intrauterine life is associated with shorter telomere length in young adulthood. Proc Natl Acad Sci U S A 2011; 108: E513-8.

13. Entringer S, Epel ES, Lin J et al. Maternal psychosocial stress during pregnancy is associated with newborn leukocyte telomere length. Am J Obstet Gynecol 2013; 208: 134.e1-7.

14. Asok A, Bernard K, Roth TL et al. Parental responsiveness moderates the association between early-life stress and reduced telomere length. Dev Psychopathol 2013; 25: 577-85.

15. Brody GH, Yu T, Beach SR et al. Prevention effects ameliorate the prospective association between nonsupportive parenting and diminished telomere length. Prev Sci 2015; 16:171-80.

16. Drury SS, Theall K, Gleason MM et al. Telomere length and early severe social deprivation: linking early adversity and cellular aging. Mol Psychiatry 2012: 17: 719-27

17. Shalev I, Moffitt TE, Sugden K et al. Exposure to violence during childhood is associated with telomere erosion from 5 to 10 years of age: a longitudinal study. Mol Psychiatry 2013; 18: 576-81.

18. Drury SS, Mabile E, Brett ZH et al. The association of telomere length with family violence and disrup tion. Pediatrics 2014; 134: e128-37.

19. Mitchell C, Hobcraft J, McLanahan SS et al. Socia disadvantage, genetic sensitivity, and children's telomere length. Proc Natl Acad Sci U S A 2014 111: $5944-9$.

20. Glass D, Parts L, Knowles D et al. No correlation between childhood maltreatment and telomere length. Biol Psychiatry 2010; 68: e21.

21. Kananen L, Surakka I, Pirkola S et al. Childhood adversities are associated with shorter telomer length at adult age both in individuals with an anxiety disorder and controls. PLOS ONE 2010; 5: e10826.

22. Tyrka AR, Price LH, Kao HT et al. Childhood maltreatment and telomere shortening: preliminary support for an effect of early stress on cellular aging. Biol Psychiatry 2010: 67: $531-4$

23. Kiecolt-Glaser JK, Gouin JP, Weng NP et al. Childhood adversity heightens the impact of later-life caregiving stress on telomere length and inflammation. Psychosom Med 2011; 73: 16-22.

24. O'Donovan A, Epel E, Lin J et al. Childhood trauma associated with short leukocyte telomere length in posttraumatic stress disorder. Biol Psychiatry 2011: 70: 465-71.
25. Surtees PG, Wainwright NW, Pooley KA et al. Life stress, emotional health, and mean telomere length in the European Prospective Investigation into Cancer (EPIC)-Norfolk population study. J Gerontol A Biol Sci Med Sci 2011; 66: 1152-62.

26. Jodczyk S, Fergusson DM, Horwood LJ et al. No association between mean telomere length and life stress observed in a 30 year birth cohort. PLoS ONE 2014; 9: e97102.

27. Savolainen K, Eriksson JG, Kananen L et al. Associations between early life stress, self-reported traumatic experiences across the lifespan and leukocyte telomere length in elderly adults. Biol Psychol 2014; 97: 35-42

28. Zalli A, Carvalho LA, Lin J et al. Shorter telomeres with high telomerase activity are associated with raised allostatic load and impoverished psychosocial resources. Proc Natl Acad Sci U S A 2014; 111: 4519-24

29. Tyrka AR, Parade SH, Price LH et al. Alterations of mitochondrial DNA copy number and telomere length with early adversity and psychopathology. Biol Psychiatry 2015; e-publisert 15.12015

30. Adams J, Martin-Ruiz C, Pearce MS et al. No association between socio-economic status and white blood cell telomere length. Aging Cell 2007; 6: $125-8$

31. Batty GD, Wang Y, Brouilette SW et al. Socioeconomic status and telomere length: the West of Scotland Coronary Prevention Study. J Epidemiol Community Health 2009; 63: 839-41.

32. Kajantie E, Pietiläinen KH, Wehkalampi K et al. No association between body size at birth and leucocyte telomere length in adult life-evidence from three cohort studies. Int J Epidemiol 2012 41. $1400-8$

33. Needham BL, Fernandez JR, Lin J et al. Socioeconomic status and cell aging in children. Soc Sci Med 2012; 74: 1948-51.

34. Robertson T, Batty GD, Der G et al. Is telomere length socially patterned? Evidence from the West of Scotland Twenty-07 Study. PLoS ONE 2012; 7: e41805.

35. Carroll JE, Diez-Roux AV, Adler NE et al Socioeconomic factors and leukocyte telomere length in a multi-ethnic sample: findings from the multiethnic study of atherosclerosis (MESA). Brain Behav Immun 2013; 28: $108-14$.

36. Cohen S, Janicki-Deverts D, Turner RB et al. Childhood socioeconomic status, telomere length and susceptibility to upper respiratory infection. Brain Behav Immun 2013; 34: 31-8.

37. Theall KP. Brett ZH, Shirtcliff EA et al. Neighborhood disorder and telomeres: connecting children's exposure to community level stress and cellular response. Soc Sci Med 2013; 85: 50-8.

38. Price LH, Kao H-T, Burgers DE et al. Telomeres and early-life stress: an overview. Biol Psychiatry 2013: 73: 15-23.

39. Aviv A, Hunt SC, Lin J et al. Impartial comparative analysis of measurement of leukocyte telomere length/DNA content by Southern blots and qPCR Nucleic Acids Res 2011: 39: e134.

40. Dlouha D, Maluskova J, Kralova Lesna I et al. Comparison of the relative telomere length measured in leukocytes and eleven different human tissues. Physiol Res 2014; 63 (suppl 3): S343-50.

41. Miller GE, Chen E, Parker KJ. Psychological stress in childhood and susceptibility to the chronic dise ases of aging: moving toward a model of behavioral and biological mechanisms. Psychol Bull 2011 137: 959-97.

42. Lin J, Epel E, Blackburn E. Telomeres and lifestyle factors: roles in cellular aging. Mutat Res 2012 730: 85-9.

43. Shalev I. Early life stress and telomere length: investigating the connection and possible mechanisms: a critical survey of the evidence base, research methodology and basic biology. BioEssays 2012; 34: $943-52$

Mottatt 6.10. 2014, første revisjon innsendt 15.4 2015, godkjent 9.6. 2015. Redaktør: Sigurd Høye. 